\title{
CORRELATION \\ BETWEEN HUMAN DEVELOPMENT \\ AND SUSTAINABLE DEVELOPMENT - CONDITION OF HUMAN SECURITY
}

\author{
Mihai-Marcel NEAG \\ mmneag@yahoo.com \\ Elisabeta-Emilia HALMAGHI \\ emmahalmaghi@gmail.com \\ “NICOLAE BĂLCESCU” LAND FORCES ACADEMY, SIBIU, ROMANIA
}

\begin{abstract}
For the sake of contemporaneity, the notion of sustainable development has become the key concept in developing new paradigms of human survival, in designing new ways of managing social systems. The current state of today's humanity is looking for a new development model as well as new security objectives.

Considered as a process over time, human development means creating, through action at policy level, the conditions for facilitating sustainable human development, such as appropriate education, health, material wellbeing, participation, social empowerment and inclusion and establishment of a model of socially and geographically equitable economic growth.
\end{abstract}

\section{KEYWORDS: \\ Human development, human security, sustainable development.}

\section{Introduction}

The present study focuses explicitly on the connections between three fundamental concepts for explaining the human being's situation: human development, human security and sustainable development. In the following lines we intend to build the framework for the problem rather than giving a more rigorous definition of the three concepts. Apart from the problematic aspects which each of them raises, the problem of their unitary approach, as a holistic interpretation of the human being, of overcoming the fragmentary, reductionist way of modelling the social existence of the people.

2. The concepts of human development, sustainable development and human security in an actual approach

In the literature, those regions and states where people have the freedom to choose their way of life, education and careers, but also political freedom, etc. are considered to be developed. Human development is a process and, at the same 
time, a result, focusing on the results of wider possibilities to choose. Human development can be defined in the easiest way as a process of expanding options: every day, a human being makes a series of economic, social, political and cultural choices. The ultimate goal of human development is not to create greater wealth or achieve greater economic growth, but the expansion of choices for every human being (Human Development Report, 2001).

According to the concept of human development, economic growth is only an important means, but in no way the ultimate goal of development. Revenue is an important contribution when its benefits are translated into people's lives, but revenue growth must not be an end in itself. The ultimate goal of development is to increase people's capabilities (Human Development Report, 2001). People's choices are expanding when they gain more abilities and enjoy more opportunities to use these skills. Human development reflects a balance between capabilities and opportunities and, if there is a disagreement between them, human frustration can be reached.

Human development, focusing on the opportunities to make choices, presupposes that people have to influence the process that shapes their lives. In other words, people have to participate in different decision-making processes, implementing these decisions and monitoring them.

Development is usually defined mainly in terms of economic growth: as countries register growth, we say that they are developing. But as long as the world's population is steadily growing, it is difficult to imagine growth without economic growth. Therefore, the issue of managing the serious effects of economic activities on the environment can no longer be just a matter exclusively on the agenda of the scientific forums, and the principles of ecology can and should also be applied in the economic sphere.

Sustainable development has as its primary objective to improve the quality of citizens' lives, at the same level of use of natural resources, without impairing the capacity to regenerate the environment. The most commonly used definition of sustainable development is that of the Brundtland Report, Our Common Future: "sustainable development is that development that meets the needs of the present without compromising the ability of future generations to meet their own needs" (Report of the World Commission on Environment and Development: Our Common Future).

For development to be truly sustainable, it is necessary to assume the political commitment of all the world's states, as well as to the closer collaboration between the specialists in the economy, environmental protection and social development. Ideally, as a result of the planning and management of natural resources, environmental factors should be minimally affected and people's living conditions improved.

The United Nations report entitled The Human Development Report published in 1994, has brought the concept of "human security" to the forefront (Human Development Report 1994, p. 23). The document was a preamble to the World Summit for Social Development, to be held in Copenhagen in March 1995, with an agenda of key topics, among which human security was of utmost relevance. The idea underlying the concept of human security is not new, as it was stated at the UN Conference in San Francisco in 1945 when it was acknowledged that the sustainable security of mankind can be ensured only if two challenges (the human security components), expressed suggestively by the phrases: freedom from fear and freedom from want are achieved.

The Report attempts to define the concept of human security by explaining its extension: security against chronic threats such as hunger, disease or oppression, as well as hurtful disruptions in everyday life at home, at work, or in communities. 
The authors of the Report have characterized the global situation as being marked by major changes, the emergence of new concerns of the people, and have explained the need for these developments to be reflected but also to be guided by the way in which security is conceived. It was practically a change of paradigm in the interpretation of security: secondly, the concern for the nation-state situation, lack of threats to its unity and independence, are set in the background and people are brought to the foreground.

Although the need for a paradigm shift is firmly argued, yet we appreciate it, and by this we subscribe to the interpretations of other authors (Gasper, 2004), according to which the report does not excel in the methodological rigor. A first indication of this is, for example, the enumeration of the essential features of the concept (universality, interdependence, ease of provision through preventive interventions, human focusing) before providing a rigorous definition of the concept. In fact, in relation to the latter aspect, the authors of the report acknowledge the difficulty of a definition of a concept which by its meanings can be matched with terms such as human freedom in the category called by WB Gallie as essentially contested concepts (Gallie, 1956). And yet, instinctively, most people understand what security means and, in order to support this point of view, a text box titled Human Security - as People see it was introduced (Human Development Report 1994).

Ensuring human security implies, above all, ensuring people's freedom of action, for in the new vision, security means the responsibility of one's own life, the ability of man to take care of himself. Thus, according to the authors of the report, the concept in question is an integrative character, the possibility of its application being ensured by consensus, not by the force of weapons.
The three concepts proposed for analysis in this study implicitly reflect the present level of mankind's interpretations of one's own being. First of all, what is surprising is the novelty of the concerns in the sphere of those notions. It is almost unbelievable that people have been able to create such high-tech technologies but have not been able to assess their impact on the environment. Equally surprising is that economic development could be considered for centuries an end in itself without "accounting for" and to what extent this development is useful to people. It is also equally paradoxical that national security has proved to be a misleading desideratum in relation to the objective of ensuring the security of citizens.

All these contradictory situations gradually begin to be overcome under the pressure of the refusals that the old concepts of development and security suffer from. Studies are still in their early, pre-paradigmatic stages. For example, the relationship between human security and human development is still not very clear. In our opinion, first of all, the two must not be confused and the link between them must be interpreted as a dynamic interdependence. While human development is a broader concept that seeks to identify and capitalize on the capabilities of human beings, human security aims at providing the necessary framework for the free and safe expression of those capabilities. The success or failure of one brings success or failure to the other because the two states stand up and mutually potentiate.

It is also noteworthy that the three concepts do not make up a unitary one, although intuitively they appear to be parts of the same whole, respectively the good interpretation of the human being. In this respect, we appreciate that a concept such as sustainable social development can be that binder concept that, starting from unitary and non-contradictory premises, can 
cover the range of preoccupations included in the semantic sphere of the concepts analysed above.

Through sustainable social development, we primarily consider the development of the human being and of the social organizations that it maintains in functional variants that do not produce undesirable results and consequences. This development should not be limited only to the use of natural resources but to all areas of human existence. For example, developing people as "subjects" of organizations and abandoning the concepts that they regard them as "labour force" can and must be a major direction of study and action.

Second, we consider the need to explore the capabilities of the human being, the recognition that this process is at its beginning and that per capita income is not determinant in this endeavour. In our opinion, it is rather a good interpretation of these aspects, the material side having its importance, but not being exclusive.

\section{Individual security and state security, an ambivalent relationship}

Conceptual changes to the security paradigm required radical reforms at the level of each national security system, with direct implications for democratic mechanisms at the level of each state. In the same context, the transformations in the conceptual perspective have profound implications on the way in which the state's attributions to security are institutionalized. Specifically, we are talking about rethinking how defence, public order and security issues are approached, the role and place of each institution, how they interact to ensure the security of the state and individuals.

Marc Crepon argues that any democracy is, or should be, concerned to answer the question "how can we make sure that the security measures taken to fight the alleged fears of citizens do not involve greater insecurity than that which claim to remove it?" thus, human rights and individual security are in a synergistic relationship. Individual security is an important indicator in identifying rights in danger in a particular situation (Crepon, 2006). In Crepon's view, the issue of individual security is also a security culture issue and depends largely on how each of those involved describe, express, analyse or understand the types of insecurity to which it is exposed.

The essence of democratic governance is to ensure leadership in accordance with the free will and the expressed interests of the population. This symbiotic relationship involves the creation of representative institutions at all levels to ensure respect for the political, social and economic rights of citizens. By the very constitutional democratic construction, the distribution of state power ensures the creation of the lever system so necessary to prevent the risky accumulation of power. Establishing a balance between how much freedom the individual has or can give to security is undoubtedly the main concern for all those involved in human rights defenders, defence staff, public order and security, and last but not least, parliamentarians and academics.

Security, at any level, is about individuals. Developing the concept of human security is an attempt by a part of the academic community to redefine and broaden the significance of security. The concept of human security focuses on the individual as the main object of security and serves the purpose of highlighting some critical issues, particularly those relating to intra-state violence. The concept of human security highlights the fact that for national security it is necessary to secure the citizens inside the states against the internal political violence, often generated by the bad governance. History abounds in examples of states that have turned against 
their own citizens, despite the philosophy of international relations theory that the state fulfills its fundamental role in ensuring the security of its citizens in an anarchic international environment.

The main point in addressing human security is the need to protect human life. Barry Buzan wrote: "... there is an inevitable contradiction between individual security and national security. It has its roots in the nature of political collectivities. In the real world, it can neither be solved, nor bypassed. Since the state is ultimately supported by its physical base, the protection of the territory and the population must count as fundamental concerns of national security, although they may sometimes be sacrificed to a considerable extent to protect the other state components" (Buzan, 2000, p. 61).

Civil Society, through its specialized organizations, should be one of the main factors to achieve the individual's security at all levels: military, political, economic, social, cultural and environmental. On the opposite side, the civil society's passivity, or even its non-existence in a structured form, can result in serious situations of disunity and chaos, and perhaps the increase in the number of risks and vulnerabilities within that society. On the other hand, we cannot ignore the special nature of the security sector, with its specific features especially related to transparency and freedom to provide information. That is why the establishment of democratic control must be adapted to the particularities of this sector so that the final result balances in a satisfactory manner the imperatives of national security on the one hand and on the other hand the democratic imperatives of respect for human rights and transparent governance.

The security of a community, or of each of its individuals, cannot be studied in a distinct way over the security environment to which it belongs. No „oasis” of security can be imagined in the current context of global risks and threats. Strengthening community security can only be achieved by awareness of the need to multiply the security of each individual. At the same time, one's security must be avoided by increasing the insecurity of others.

The report of the Human Security Commission states quite clearly that security is addressed to both human beings and states, non-governmental organizations and international bodies and thus requires an extension of the concept of security beyond that of "human security". Neither "state security" within boundaries that is provided with defence, nor the safeguarding of existing institutions does not exhaust the sense of the notion nor the imperatives attached to it. From this perspective, individuals in society recognize the need for security that cannot be reduced to that which the state might claim to satisfy itself by protecting itself (Human Development Report 1994, p. 23).

Human security and human rights are in a synergy: respect for human rights is the basic prerequisite for protecting human security. Human security helps to spot human rights in a particular situation. Human rights help us answer the question of how to protect human security. The notion of rights and obligations complements the ethical and political recognition and importance of the concept of human security.

An important aspect of human security is the quality of life, which is an evaluation concept and is the result of the reporting of the living conditions and the activity that compose human life to human needs, values and aspirations. It is noted that this concept refers both to the objective conditions in which human life is constituted, and to the subjective way in which each individual evaluates their own life (Zamfir, 1978). The most important social and sociological indicators and parameters that measure objective conditions are: social and 
sociological indicators and parameters of housing, social and sociological indicators of poverty, indicators of health, indicators of human freedom and development, indicators of characterization of the education system.

\section{Human security between human development and sustainable development}

The development of mankind cannot be achieved without ensuring human security. Security means that the benefits that people have reached in expanding their opportunities and improving their capabilities are protected by current social, economic, political arrangements. The approach to human security is based on a broad social acceptance of people's rights and obligations, based on sustainable institutions. "The relevance of human security for security studies lies in the network of connections and contradictions between personal security and state security. Its importance lies also in the fact that it gives conceptual coherence to numerous governmental and non-governmental, national and international initiatives, and promotes the restatement of the relationship between the state and its citizens in cases where they are needed" (Buzan, 2000, p. 46).

The world is becoming more complex and interdependent, and the phenomenon of sustainable development is becoming more and more irreversible. The indissolubility and commensurability of the notions of development and security, their interconnection and dialectical interdependence have also become evident (Ţîrdea, 2001).

Concerns about the future of humanity, and from this perspective, the issues of ensuring sustainable development that lead to the improvement of the quality of life in a balanced and global way are more and more frequently mentioned in the international discourse analysing the stage of human development, the progress obtained is appreciated and the deficiencies that persist in different fields are signalled. These objectives highlight the Millennium Goals which refer to: "eradication of extreme poverty and hunger; ensuring universal primary education; promoting gender equality; reducing child mortality; improving maternal health; combating diseases such as HIV/AIDS, malaria and tuberculosis; ensuring sustainable development; developing a global partnership for development" (Millennium Development Goals, 2011).

Human development in the UN concept is described as a process of broadening the range of people's choices, based on the strengthening of their basic capabilities, expressed through the relationship between vital human needs and material factors. Focusing attention on human development reflects the tendency towards a fundamental reorientation of the goals according to which social reforms are adopted in the contemporary world. Human development is closely linked to the individual's freedoms and dignity, the expansion of freedoms lies at the heart of the concept and must also underpin its implementation. The objectives of human development are in close correlation with those of the need to ensure the appropriate framework for implementation, namely the achievement of the objectives for achieving the optimal framework, that of human security.

Sustainable development is essentially the answer to the emergence of environmental problems and the crisis of natural resources, especially those related to energy. Practically, it is recognized that human activities contribute to the deterioration of the environment, which jeopardizes the future of the Planet. Health, social safety and the economic stability of society are essential in defining the quality of life.

Development through people and for people highlights an important dimension of human development, that of citizens' participation in the creation of personal and, 
implicitly, national welfare. People are the tools and beneficiaries, but also the victims of all development activities. Any development process must have human purpose. Sustainable development is a way of development that supports human progress not only in a few places and for a few years, but for the population of the entire planet and for a long-term future. "Sustainable human development as a universal development specific to individuals and populations in their quality of purpose that subordinates the goals of the markets, government administrations, international organizations (economic, political and military) of all the institutions of contemporary society has become an operative concept in the world" (http://www.scritub.com).

Sustainable development means continuously improving the quality of life and well-being by promoting a dynamic economy through health, social and territorial cohesion and environmental protection, in a secure world which respects cultural diversity.

Sustainable development and human security are related, interdependent but not identical. Of course, there is an interconnection between human development through sustainable development and human security: progress in one area extends the possibilities for the progress of the other, and vice versa. As for the concept of human security, as with other fundamental notions (such as human freedoms), it is much easier to find the security list than its existence.

From the perspective of human security, the new complex issues of the present require clarity in the hierarchy and prioritization of strategic development objectives, the counteraction of a wide range of threats to people, grouped as follows: providing the minimum income necessary for each individual; guaranteeing access to basic food; guaranteeing minimum protection against illness and unhealthy lifestyles; protect people from environmental damage and natural disasters; protecting people from physical violence, whatever its source; protecting people from loss of traditional relations and values, ethnic and sectarian violence; providing a living environment based on respect for human rights in society.

The link between human security and sustainable development is manifested in conceptual terms from the perspective of the four basic components of human development: equality in terms of fair access to opportunities; sustainability as regards responsibility for future generations as those of the present generation; productivity on human resource investigations and creating the macroeconomic environment that would allow people to reach their full potential; the sense of decision - in the sense that people have to achieve a level of individual development that would allow them to exercise options based on their own desires from a wider framework of the existing opportunity (Buzan, 2000).

Focusing attention on human development reflects the tendency towards a main reorientation of the goals, according to which social reforms are adopted in the contemporary world. Man and his vital needs are considered fundamental, as a supreme value, while material factors, cash incomes or increased consumption are no longer a central, fundamental condition, but only a means of ensuring sustainable human development. It is remarkable that this review of the correlation between the purposes and the means of social development is only a return to that kind of orientation of general world conceptions that are characteristic of human culture in general, including for European culture, but which became diluted and even distorted due to social - historical circumstances.

The development of humanity cannot be achieved without the assurance of human security. Human security usually involves a 
condition in which people can exercise their options safely and freely, without fear that the opportunities they enjoy today will be lost or withdrawn tomorrow. Security means that the benefits that people have reached in expanding their opportunities and improving their capabilities are protected by current social, economic, political arrangements. Security is based on a broad social acceptance - based on sustainable institutions "of people's rights and obligations" (Bobiuc, 1997).

\section{Conclusions}

The primary objective of ensuring national security is to identify the risks to which the state is exposed in the context of changes in the international system. Within this framework, the ability of a state to secure its security could be translated, from the point of view of the individual, by the possibility of state structures to provide a certain level of protection against the risks to which it might be exposed. It should not, however, be neglected that ensuring the protection of the individual against external risks is not a sufficient condition for ensuring human security, especially when many of the risks to which the individual is subjected come from the internal environment.

Of course, the role of national states is not diminishing, but it is no longer the decisive one but it acquires new dimensions. Today, the conditions are met for an international coalition of states and civil society organizations to support projects aimed at placing the security of people and human communities at the centre of international security. A new international rapprochement is needed both to fight the causes of insecurity and to find together solutions to solving the dangers and threats of millions of people every day.

The promoters of the human security field argue that, in the context of the current evolution of humanity, it is necessary to be aware of the central role of the individual, namely of human security, in ensuring the stability of security systems at national, regional and even global level. Human security means a phenomenon with many components: economic security, food security, health security, environmental security, personal security, public security, political security. The mentioned structural elements of human security are of particular importance to man in any country, in any social situation, but the security issues of the present are required to be formulated and resolved from the perspective of the future.

The new vulnerabilities, risks and threats facing mankind today require, at the beginning of this century, that the concept of security must articulate around the principles of international security, national security and human security. Strengthening security must be based on two main elements: strengthening the sense of trust between people (as a result of informational connections within the state) and promoting collaboration between states. In this context, sustainable development must ensure human security through the dimension of economic efficiency, social equity and environmental protection.

Also, human security suggests a multidimensional approach, including human survival measures, which leads us to the conclusion that human security is universal in nature because actions in this area go beyond national borders and aim at understanding and realizing human security in a unitary way.

For the sake of contemporaneity, the notion of "sustainable development" has become the key notion in developing new paradigms of human survival, in designing new ways of managing social systems. The current state of today's humanity is looking for a new development model as well as new security objectives. Ensuring overall security is possible in sustaining global sustainable development. 


\section{REFERENCES}

Bobiuc, V. (1997). Securitatea României o perspectivă europeană. Strategii XXI. Viitorologie. Geopolitică. Strategii operaţionale. Bucureşti.

Buzan, B. (2000). Popoarele, statele şi teama, Chişinău: Cartier.

Crepon, M. (2006). Securitatea individului şi securitatea statului, o relaţie ambivalentă. IDEA artă + societate, 25, available at: www.idea.ro, accessed on 15 May 2019.

European Commission. (2011). Millennium Development Goals: EU gives additional support to 36 countries for tackling major development challenges, available at: http://europa.eu/rapid/press-release MEMO-11-930 en.htm, accessed on 15 May 2019.

Gallie, W. B. (1956). Essentially Contested Concepts. Proceedings of the Aristotelian Society, Vol. 56, Issue 1.

Gasper, D. (2004). Securing Humanity: Situating "Human Security" as Concept and Discourse. Journal of Human Development and Capabilities, Vol. 6 (2), 221-245.

Managementul dezvoltării umane durabile. (2019). available at: http://www.scritub. com/management/MANAGEMENTUL-DEZVOLTARII-UMANE34132.php, accesed on 25 April 2019.

Ţîrdea, T. N. (2001). Elemente de informatică socială, sociocognitologie şi noosferologie. Chişinău.

UN-Documents. (f.a.). Report of the World Commission on Environment and Development: Our Common Future, available at: http://www.un-documents.net/wcedocf.htm, accessed on 25 April 2019.

United Nations Development Programme. (1994). Human Development Report 1994, available at: http://hdr.undp.org/sites/default/files/reports/255/hdr_1994_en_complete nostats.pdf, accesed on 25 April 2019.

United Nations Development Programme. (2001). Human Development Report 2001, Making New Technologies Work for Human Development, available at: http://hdr.undp.org/ sites/default/files/reports/262/hdr_2001_en.pdf, accesed on 25 April 2019.

Zamfir, C. (1978). Calitatea vieții. In: Zamfir, C., \& Vlăsceanu, L. Dicţionar de sociologie (pp. 79-80). Bucureşti: Editura Babel. 